\title{
Article \\ Effect of Cold Storage on the Quality of Psyttalia incisi (Hymenoptera: Braconidae), a Larval Parasitoid of Bactrocera dorsalis (Diptera: Tephritidae)
}

\author{
Jia Lin ${ }^{1,2,3}$, Deqing Yang ${ }^{1,2,3}$, Xuxing Hao ${ }^{1,2,3}$, Pumo Cai ${ }^{1,2,3,4}$, Yaqing Guo ${ }^{1,2,3}$, Shuang Shi ${ }^{1,2,3}$, \\ Changming Liu ${ }^{1,2,3}$ and Qinge Ji ${ }^{1,2,3, *}$
}

1 Institute of Beneficial Insects, Plant Protection College, Fujian Agriculture and Forestry University, Fuzhou 350002, China; Linjia@fafu.edu.cn (J.L.); 3200231054@fafu.edu.cn (D.Y.); 1200203004@fafu.edu.cn (X.H.); caipumo@fafu.edu.cn (P.C.); 3190231007@fafu.edu.cn (Y.G.); 1190203017@fafu.edu.cn (S.S.); cmliu@fjau.edu.cn (C.L.)

2 Key Laboratory of Biopesticide and Chemical Biology, Ministry of Education, Fuzhou 350002, China 3 State Key Laboratory of Ecological Pest Control for Fujian and Taiwan Crops, Fuzhou 350002, China 4 Department of Horticulture, College of Tea and Food Science, Wuyi University, Wuyishan 354300, China

* Correspondence: jiqinge@fafu.edu.cn

check for updates

Citation: Lin, J.; Yang, D.; Hao, X.; Cai, P.; Guo, Y.; Shi, S.; Liu, C.; Ji, Q. Effect of Cold Storage on the Quality of Psyttalia incisi (Hymenoptera: Braconidae), a Larval Parasitoid of Bactrocera dorsalis (Diptera:

Tephritidae). Insects 2021, 12, 558. https://doi.org/10.3390/insects 12060558

Academic Editor: Man P. Huynh

Received: 11 May 2021

Accepted: 4 June 2021

Published: 16 June 2021

Publisher's Note: MDPI stays neutral with regard to jurisdictional claims in published maps and institutional affiliations.

Copyright: (c) 2021 by the authors. Licensee MDPI, Basel, Switzerland. This article is an open access article distributed under the terms and conditions of the Creative Commons Attribution (CC BY) license (https:// creativecommons.org/licenses/by/ $4.0 /)$.
Simple Summary: Biological control programs primarily rely on the mass-release of high-quality bioagents in order to successfully suppress pests. However, producing such bioagents on a large scale and within a short timeframe or in a single step is extremely difficult. Therefore, it is important to consider methods that could increase the shelf life and help to synchronize the release schedule of bioagents reared in different batches. In the present study, we determined the effects of various cold storage protocols on the emergence and quality of Psyttalia incisi, a larval parasitoid of Bactrocera dorsalis. Our results indicated that there were no negative impacts on the emergence parameters and adult quality when late-age $P$. incisi pupae were stored at $13{ }^{\circ} \mathrm{C}$ for 10 or $15 \mathrm{~d}$. This information is valuable in facilitating the mass-rearing of $P$. incisi and helping to improve the efficiency of biological control programs using $P$. incisi against $B$. dorsalis.

Abstract: Psyttalia incisi (Silvestri) is the dominant parasitoid against Bactrocera dorsalis (Hendel) in fruit-producing regions of southern China. Prior to a large-scale release, it is important to generate a sufficient stockpile of $P$. incisi whilst considering how best to maintain their quality and performance; cold storage is an ideal method to achieve these aims. In this study, the impacts of temperature and storage duration on the developmental parameters of $P$. incisi pupae at different age intervals were assessed. Then, four of the cold storage protocols were chosen for further evaluating their impacts on the quality parameters of post-storage adults. Results showed that the emergence rate of $P$. incisi was significantly affected by storage temperature, storage duration, and pupal age interval and their interactions. However, when late-age P. incisi pupae developed at a temperature of $13^{\circ} \mathrm{C}$ for 10 or $15 \mathrm{~d}$, no undesirable impacts on dry weight, flight ability, longevity, reproduction parameters of post-storage adults, emergence rate, or the female proportion of progeny were recorded. Our findings demonstrate that cold storage has the potential for enhancing the flexibility and effectiveness of the large-scale production and application of $P$. incisi.

Keywords: Psyttalia incisi; oriental fruit fly; cold storage; emergence rate; quality; reproduction

\section{Introduction}

Batrocera dorsalis (Hendel) (Diptera: Tephritidae) is a notorious pest of economic importance, largely due to its traits of polyphagia, superior dispersal ability, outstanding climate adaptability, and high fecundity [1]. Over the last two decades, this fly has spread into many tropical and subtropical regions due to both human transportation and adult fly 
migration, causing considerable damage to commercial fruits and horticultural products as well as the associated import and export trade [2,3]. At present, the primary strategy for suppressing this pest involves spraying chemical insecticides, either alone or in combination with food-based lures [4]. However, there are numerous problems associated with this strategy, including insecticide resistance, environmental depredation, and effects on food safety, which has led to pressure for an alternative strategy to be developed [5,6]. Biological control, which has the advantages of being long-lasting and environmentally friendly, has recently gained much attention and is regarded as the prime alternative tactic against $B$. dorsalis populations [7].

Psyttalis incisi (Silvestri) (Hymenoptera: Braconidae: Opiinae) is a solitary opiine endoparasitoid, whose preferential host is the early larval instar of $B$. dorsalis [8]. It has been reported that $P$. incisi exist naturally and occupy a dominant proportion $(77.6 \%)$ of the parasitic wasp population against $B$. dorsalis in fields of Zhangzhou City, Fujian Province, $C$ ina, and contributed a limited reduction in B. dorsalis populations [9]. Hence, $P$. incisi is a highly suitable bioagent for biological control programs against $B$. dorsalis in that region of China. However, in order for such programs to be effective, millions of parasitoids need to be first produced and then transported into the affected areas. In order to improve the ease at which this can be achieved, it is important to consider methods by which the shelf life of $P$. incisi can be increased. This will help to ensure a sufficient stockpile of parasitoids and allow releases to be appropriately timed given their physiological characteristics.

Exposing bioagents to low temperatures can extend their developmental duration and is particularly valuable for the inundative biological control program which entailed a large number of biocontrol agents [10]. However, keeping parasitoids at a sub-ambient temperature can result in cold injuries and excessive consumption of energy reserves, resulting in undesirable effects on the quality and quantity of post-storage parasitoids [11]. Hence, to minimize losses in the performance of parasitoids after undergoing storage, packaging, and shipment, recent research has focused on optimizing the tradeoffs between quality and the cold storage protocol [12-14]. For braconid parasitoids against tephritid pests, the impacts of cold storage have been evaluated in several species, such as Psyttalia humilis (Silvestri), Psyttalia ponerophaga (Silvestri), Fopius arisanus (Sonan), and Diachasmimorpha longicaudata (Ashmead) (Hymenoptera: Braconidae); these works have provided a lot of valuable information for facilitating the practical application of biological control programs [15-17]. However, to date, cold storage has never been investigated as an auxiliary approach for the large-scale rearing and release of $P$. incisi. Owing to the vital role of $P$. incisi in the management of $B$. doralis, it is crucial to optimize the flexibility and effectiveness of large-scale production and mass-release programs of $P$. incisi through cold storage techniques.

In the present study, we first determined the effects of various storage temperatures $\left(4,7,10\right.$, and $\left.13{ }^{\circ} \mathrm{C}\right)$ and exposure durations $(10,15,20$, and 25 days) on the emergence rate of $P$. incisi at different pupal age intervals within parasitized B. dorsalis puparia. Further experiments were then carried out to examine the dry weight, flight ability, longevity, and reproduction parameters of parental $P$. incisi (G1) along with emergence rates, and the female proportion of progeny (G2).

\section{Materials and Methods}

\subsection{Insect Colonies}

Bactrocera dorsalis and P. incisi were initially collected from orchards in and around Fujian institutes of Tropical Crops (117 $30^{\prime} 58.95^{\prime \prime} \mathrm{E}, 24^{\circ} 37^{\prime} 31.37^{\prime \prime} \mathrm{N}$, and $26 \mathrm{~m}$ altitude), in Zhangzhou City, Fujian Province, China in 2004. These orchards are composed of 'Pearl' guava (Psidium guajava L.), carambola (Averrhoa carambola L.), and wax apple (Syzygium samarangense), the annual average temperature of this area was $21^{\circ} \mathrm{C}$ and annual average rainfall was $1603 \mathrm{~mm}$ [9]. Bactrocera dorsalis and P. incisi were then identified in the laboratory [18], and these vouchers were deposited in the UN (China) Center for Fruit Fly Prevention and Treatment, Fujian Agriculture and Forestry University. Bactrocera dorsalis 
were permitted to oviposit in a plastic bottle that was neatly pierced with holes; eggs were collected and transferred to a tray containing a mill feed diet for larval development, prepared in accordance with Chang et al. [19]. Puparia were collected from the bottom of the tray and transferred into a gauze cage $\left(30 \times 30 \times 30 \mathrm{~cm}^{3}\right)$ until emergence. Fly adults were provided with a diet of yeast extract and sugar $(1: 3, w t: w t)$ and water. For the rearing of $P$. incisi, excessive numbers of second-instar $B$. dorsalis larvae were transferred to an oviposition plate (diameter: $9 \mathrm{~cm}$, high: $0.5 \mathrm{~cm}$ ) which was covered with 80 mesh net to prevent larvae from escaping. Then, two oviposition plates were provided to 500 pairs of $P$. incisi adults within a cage for $24 \mathrm{~h}$ to avoid super-parasitism. Honey and water were provided for $P$. incisi adults. Bactrocera dorsalis and $P$. incisi used in the experiments were reared under the controlled conditions of $25 \pm 1{ }^{\circ} \mathrm{C}, 65 \pm 5 \%$ relative humidity $(\mathrm{RH})$, and a 12:12 h (L:D) photoperiod.

\subsection{Effects of Storage Temperature, Storage Duration and Pupal Age Interval on the Emergence Parameters of $P$. incisi}

Newly-formed $B$. dorsalis puparia were collected daily, with parasitized and unparasitized puparia distinguished by several characteristics as described in Wang and Messing [20] and Danne et al. [15]. Briefly, for parasitized puparia, the major characteristics included oviposition scars on the cuticle, a gap inside the fly pupa caused by consumption of the fly body by a parasitoid larva, and being relatively smaller and browner. For unparasitized puparia, the appendages of the fly could be clearly observed through the cuticle under a microscope.

Based on a preliminary experiment that identified the immature stage of $P$. incisi (through dissecting puparia), parasitized B. dorsalis puparia were incubated at $25^{\circ} \mathrm{C}$ for 3 , 6 , and 9 days for $P$. incisi to develop into prepupae, middle-age pupae (some appendages, the shape of abdomen and thorax are observable but without any color; eye and ocelli are rufous), and late-age pupae (body is tawny, eye and ocelli are dark, mouth is dark brown), respectively. The three developmental stages were subsequently stored in four incubators (PRX-25013, Safu, Ningbo, China) set at constant low temperatures $(4,7,10$, and $13{ }^{\circ} \mathrm{C}$, respectively) for four durations $(10,15,20$, and $25 \mathrm{~d})$, all at $75 \% \mathrm{RH}$. A control group comprised parasitized puparia that developed in an incubator set at $25{ }^{\circ} \mathrm{C}$ and $75 \%$ RH until emergence. For each treatment and control, Petri dishes contained 30 parasitized puparia each were prepared. To ensure a ventilated condition to avoid the outbreak of pathogens, gauze was used to cover the dishes. Dishes were randomly assigned to the various treatment groups and inspections of each incubator were performed daily (for $30 \mathrm{~s}$ ) to observe whether $P$. incisi adults had emerged during the cold exposure period. After cold exposure, treatments were held under control conditions and the number and sex of emerged $P$. incisi adults were recorded daily. All unemerged puparia of each treatment were dissected 5 days after the last $P$. incisi emerged or 15 days after cold treatment protocol (for those treatments without $P$. incisi emerged). A total of nine replicates were performed for this experiment.

\subsection{Effects of Pupal Cold Storage on Quality of P. incisi Adults}

To determine the effects of cold exposure on the G1 quality and G2 emergence parameters, four pupal cold storage protocols that did not have significant negative impacts on the emergence rate of $P$. incisi were selected for further experiments based on the results of Experiment 2.2. After the cold storage protocol, this series of bioassays were conducted under controlled conditions of $25 \pm 1{ }^{\circ} \mathrm{C}$ and $65 \pm 5 \% \mathrm{RH}$.

The four cold storage protocols were as follows:

Cold storage 1 (CS1): late-age $P$. incisi pupa (9-day-old parasitized B. dorsalis puparia) stored at $13{ }^{\circ} \mathrm{C}$ for 10 days;

Cold storage 2 (CS2): middle-age $P$. incisi pupa (6-day-old parasitized B. dorsalis puparia) stored at $13{ }^{\circ} \mathrm{C}$ for 10 days;

Cold storage 3 (CS3): late-age $P$. incisi pupa (9-day-old parasitized B. dorsalis puparia) stored at $13{ }^{\circ} \mathrm{C}$ for 15 days; 
Cold storage 4 (CS4): middle-age P. incisi pupa (6-day-old parasitized B. dorsalis puparia) stored at $13^{\circ} \mathrm{C}$ for 15 days.

\subsubsection{Dry Weight}

Parasitized puparia were transferred to a plastic bowl within a gauze cage. Parasitoids that had emerged within $24 \mathrm{~h}$ without foraging any food were used in this bioassay. For each treatment, 1 group of 50 females and 1 group of 50 males were respectively placed inside a total of 6 centrifuge tubes. All adults were kept at $-20{ }^{\circ} \mathrm{C}$ for $20 \mathrm{~min}$ and were then dried in an oven at $60^{\circ} \mathrm{C}$ for $48 \mathrm{~h}$. Subsequently, the gross dry weight of a cohort of 50 females or males from each group was measured using a semimicro balance (CP225D, accuracy of $0.01 \mathrm{mg}$, Sartorius, Göttingen, Germany). Nine replicates were conducted in this experiment.

\subsubsection{Flight Capacity}

Fifty newly-emerged $(<24 \mathrm{~h})$ females and 50 newly-emerged males were caught using $5 \mathrm{~mL}$ centrifuge tubes. These centrifuge tubes were held at $4{ }^{\circ} \mathrm{C}$ for $10 \mathrm{~s}$ to immobilize the adult wasps. Subsequently, two tubes each of females and males were placed into a hollow black cylinder that had been placed in the center of a cage and the lids of these tubes were opened and no longer closed to allow them to escape. Talc powder was uniformly daubed around the interior of the black cylinder to ensure that adults could not climb out. To provide illumination, a $30 \mathrm{~W}$ fluorescent light was directed at the top of the cage from a distance of $20 \mathrm{~cm}$. The collection of fliers was performed every $12 \mathrm{~h}$. The experiment was performed until all parasitoid wasps were dead. The flight capacity was calculated as (the total number of $P$. incisi flew out the hollow black cylinder / the total number of $P$. incisi used) $\times 100 \%$. For each treatment, nine replicates of this experiment were conducted.

\subsubsection{Longevity and Reproductive Parameters}

Pairs of $P$. incisi adults that had emerged within $24 \mathrm{~h}$ were confined in individual centrifuge tubes to observe mating behavior; this ensured that all adults used in this experiment were mated. Subsequently, each pair of P. incisi adults were transferred into a plastic jar (diameter: $15 \mathrm{~cm}$, high: $10 \mathrm{~cm}$ ) and the top was wrapped with gauze for ventilation. Honey and water were provided: honey was daubed on the gauze and water was absorbed in a sponge inside the plastic jar. Excessive numbers of second-instar $B$. dorsalis larvae were transferred to a small oviposition plate (diameter: $3.5 \mathrm{~cm}$, high: $0.5 \mathrm{~cm}$ ) that was covered with 80 mesh net, and then a small oviposition plate was provided for $P$. incisi adults to parasitize for $24 \mathrm{~h}$. The larvae were refreshed daily until the female had died. After parasitism, larvae were reared on artificial diets until pupation. Larvae and pupae that died during development were removed for further observation and dissection under a microscope to determine whether they had been parasitized. The number of both sexes of the progeny of each treatment and control were documented daily. The pre-oviposition period, oviposition period, post-oviposition period, longevity of G1, and emergence rate as well as the female proportion of $\mathrm{G} 2$ were recorded for each treatment and control. A total of 15 replicates were performed for each treatment.

\subsection{Statistical Analysis}

All data were analyzed after checking that the data were normally distributed and there was homogeneity of variances (SPSS Inc., Chicago, IL, USA). Percentage data were arcsine square-root-transformed for further statistical analysis; however, untransformed data are presented in tables. The effects of storage temperature, storage duration, pupal age interval, and their interactions on emergence and proportion of female G1 were analyzed by univariate three-way ANOVA (generalized linear model, GLM). One-way ANOVA was conducted to analyze the effects of the pupal cold storage protocol on dry weight, flight ability, longevity, and reproduction parameters of G1 P. incisi adults and the emergence rate and female proportion of G2. Differences between treatments and control were assessed 
using a one-way ANOVA with Tukey's honestly significant difference (HSD) test $(p<0.05)$ for multiple mean comparisons.

\section{Results}

\subsection{Effects of PupalCold Storage on the Emergence Parameters of P. incisi}

\subsubsection{Emergence Rate}

A significant difference was observed in the emergence rate of $P$. incisi among storage temperature $\left(F_{3,432}=1286.705, p<0.001\right)$, storage duration $\left(F_{3,432}=426.532, p<0.001\right)$, pupal age interval $\left(F_{2,432}=196.2910, p<0.001\right)$, storage temperature $\times$ storage duration $\left(F_{9,432}=12.342, p<0.001\right)$, storage temperature $\times$ pupal age interval $\left(F_{6,432}=68.522\right.$, $p<0.001)$, storage duration $\times$ pupal age interval $\left(F_{6,432}=6.573, p<0.001\right)$, and their interactions $\left(F_{18,432}=3.881, p<0.001\right)$.

Overall, the emergence rate of $P$. incisi pupae of the same age decreased as temperature decreased and storage duration increased. Regardless of pupal age interval and storage duration, $P$. incisi pupae stored at 4,7 , and $10^{\circ} \mathrm{C}$ exhibited significantly lower emergence rates compared to the control group. However, no significant differences were observed for middle-age $P$. incisi pupae stored at $13{ }^{\circ} \mathrm{C}$ for 10 days $(p=1.000)$ and 15 days $(p=0.343)$ as well as late-age $P$. incisi pupae stored at $13{ }^{\circ} \mathrm{C}$ for 10 days $(p=1.000)$ and 15 days $(p=0.779)$ in comparison with the control group. Surprisingly, after being subjected to the same cold storage protocol of 4,7 , and $10^{\circ} \mathrm{C}$, middle-age $P$. incisi pupae presented the highest emergence rate compared to the prepupae and late-age pupae (Table 1).

Table 1. Emergence rate of $P$. incisi after being subjected to different pupal cold storage treatments $(n=9)$.

\begin{tabular}{|c|c|c|c|c|}
\hline \multicolumn{5}{|c|}{ Emergence Rate (\%) } \\
\hline \multirow{2}{*}{$\begin{array}{c}\text { Storage } \\
\text { Temperature }\left({ }^{\circ} \mathrm{C}\right)\end{array}$} & \multirow{2}{*}{$\begin{array}{l}\text { Storage } \\
\text { Time (d) }\end{array}$} & \multicolumn{3}{|c|}{ Pupal Age Interval } \\
\hline & & Prepupae & Middle-Age & Late-Age \\
\hline \multirow{4}{*}{4} & 10 & $7.57 \pm 1.66 \mathrm{c}$ & $16.84 \pm 1.96 \mathrm{~b}$ & $4.55 \pm 1.13 \mathrm{~cd}$ \\
\hline & 15 & $1.77 \pm 0.89$ ef & $6.64 \pm 1.50 c$ & $0 \mathrm{f}$ \\
\hline & 20 & $0 \mathrm{f}$ & $1.14 \pm 0.76 \mathrm{f}$ & $0 \mathrm{f}$ \\
\hline & 25 & $0 \mathrm{f}$ & $0 \mathrm{f}$ & $0 \mathrm{f}$ \\
\hline 25 (control) & & & $83.27 \pm 2.36 \mathrm{a}$ & \\
\hline \multirow{4}{*}{7} & 10 & $13.71 \pm 2.17 \mathrm{c}$ & $25.22 \pm 2.74 b$ & $11.47 \pm 1.28 \mathrm{c}$ \\
\hline & 15 & $3.43 \pm 1.2 \mathrm{de}$ & $11.08 \pm 0.87 c$ & $1.53 \pm 0.84 \mathrm{de}$ \\
\hline & 20 & $0.51 \pm 0.51 \mathrm{e}$ & $5.44 \pm 1.63 \mathrm{~d}$ & $0 \mathrm{e}$ \\
\hline & 25 & $0 \mathrm{e}$ & $0 \mathrm{e}$ & $0 \mathrm{e}$ \\
\hline 25 (control) & & & $83.27 \pm 2.36 \mathrm{a}$ & \\
\hline \multirow{3}{*}{10} & 10 & $19.03 \pm 2.02 c$ & $45.81 \pm 2.50 \mathrm{~b}$ & $39.07 \pm 3.23 b$ \\
\hline & 15 & $15.23 \pm 2.14 \mathrm{~cd}$ & $36.19 \pm 2.34 b$ & $20.05 \pm 2.04 c$ \\
\hline & 20 & $9.34 \pm 1.56 \mathrm{de}$ & $16.29 \pm 2.86 \mathrm{~cd}$ & $3.36 \pm 1.11 \mathrm{e} \mathrm{fg}$ \\
\hline 25 (control) & 25 & $2.64 \pm 0.84 \mathrm{fg}$ & $\begin{array}{l}5.46 \pm 1.42 \text { ef } \\
83.27 \pm 2.36 a\end{array}$ & $0 \mathrm{~g}$ \\
\hline \multirow{4}{*}{13} & 10 & $37.89+3.16 c$ & $81.29+2.50 a$ & $80.62+192 a$ \\
\hline & 15 & $33.52 \pm 4.32 \mathrm{~cd}$ & $73.22 \pm 2.34 \mathrm{a}$ & $75.71 \pm 3.26 \mathrm{a}$ \\
\hline & 20 & $20.06 \pm 3.06 \mathrm{~d}$ & $54.80 \pm 2.73 b$ & $59.33 \pm 2.44 b^{E}$ \\
\hline & 25 & $6.01 \pm 1.48 \mathrm{e}$ & $38.49 \pm 2.95 c^{E}$ & $46.67 \pm 2.64 \mathrm{bc}^{\mathrm{E}}$ \\
\hline 25 (control) & & & $83.27 \pm 2.36 \mathrm{a}$ & \\
\hline
\end{tabular}

Note: Data are presented as mean \pm SE. Different lowercase letters indicate significant differences at the 0.05 level by Tukey's test. Control means P. incisi pupae developed at $25^{\circ} \mathrm{C}$. ${ }^{\mathrm{E}}$ means that part of $P$. incisi have emerged during the cold storage protocol.

\subsubsection{Female Proportion}

The proportion of females was not affected by storage temperature $\left(F_{3,253}=0.469\right.$, $p=0.704)$, storage duration $\left(F_{3,253}=0.698, p=0.554\right)$, pupal age interval $\left(F_{2,253}=0.027\right.$, $p=0.973)$, storage temperature $\times$ storage duration $\left(F_{6,253}=0.490, p=0.816\right)$, storage 
temperature $\times$ pupal age interval $\left(F_{5,253}=0.093, p=0.993\right)$, storage duration $\times$ pupal age interval $\left(F_{6,253}=0.087, p=0.998\right)$, or their interactions $\left(F_{3,253}=0.069, p=0.976\right)$. There was no significant difference between the control group and all treatments (Table 2).

Table 2. Proportion of emerging $P$. incisi females after being subjected to different pupal cold storage treatments $(n=9)$.

\begin{tabular}{|c|c|c|c|c|}
\hline \multicolumn{5}{|c|}{ Female Proportion (\%) } \\
\hline \multirow{2}{*}{$\begin{array}{c}\text { Storage } \\
\text { Temperature }\left({ }^{\circ} \mathrm{C}\right)\end{array}$} & \multirow{2}{*}{$\begin{array}{l}\text { Storage } \\
\text { Time (d) }\end{array}$} & \multicolumn{3}{|c|}{ Pupal Age Interval } \\
\hline & & Prepupae & Middle-Age & Late-Age \\
\hline \multirow{4}{*}{4} & 10 & $80.21 \pm 7.56 \mathrm{a}$ & $69.51 \pm 5.06 \mathrm{a}$ & - \\
\hline & 15 & - & $72.92 \pm 11.86 \mathrm{a}$ & - \\
\hline & 20 & - & - & - \\
\hline & 25 & - & - & - \\
\hline 25 (control) & - & & $71.53 \pm 2.02 \mathrm{a}$ & \\
\hline \multirow{4}{*}{7} & 10 & $71.48 \pm 6.78 \mathrm{a}$ & $71.42 \pm 4.92 \mathrm{a}$ & $74.07 \pm 5.97 \mathrm{a}$ \\
\hline & 15 & - & $64.82 \pm 10.09 \mathrm{a}$ & - \\
\hline & 20 & - & $80.56 \pm 7.38 \mathrm{a}$ & - \\
\hline & 25 & - & - & - \\
\hline 25 (control) & & & $71.53 \pm 2.02 \mathrm{a}$ & \\
\hline \multirow{4}{*}{10} & 10 & $74.23 \pm 6.01 \mathrm{a}$ & $68.21 \pm 2.96 \mathrm{a}$ & $69.81 \pm 2.85 \mathrm{a}$ \\
\hline & 15 & $71.09 \pm 6.17 \mathrm{a}$ & $71.65 \pm 3.06 \mathrm{a}$ & $72.67 \pm 4.30 \mathrm{a}$ \\
\hline & 20 & $71.88 \pm 8.78 \mathrm{a}$ & $70.95 \pm 4.15 \mathrm{a}$ & - \\
\hline & 25 & - & $80.95 \pm 8.13 \mathrm{a}$ & - \\
\hline 25 (control) & & & $71.53 \pm 2.02 \mathrm{a}$ & \\
\hline \multirow{4}{*}{13} & 10 & $70.65 \pm 5.34 \mathrm{a}$ & $69.20 \pm 3.08 \mathrm{a}$ & $66.79 \pm 1.99 a$ \\
\hline & 15 & $69.58 \pm 4.01 \mathrm{a}$ & $70.12 \pm 2.62 \mathrm{a}$ & $68.43 \pm 1.98 \mathrm{a}$ \\
\hline & 20 & $73.70 \pm 5.78 \mathrm{a}$ & $69.23 \pm 4.06 \mathrm{a}$ & $71.56 \pm 3.21 \mathrm{a}^{\mathrm{E}}$ \\
\hline & 25 & $68.75 \pm 15.27 \mathrm{a}$ & $70.56 \pm 4.26 \mathrm{a}^{\mathrm{E}}$ & $69.42 \pm 2.43 \mathrm{a}^{\mathrm{E}}$ \\
\hline 25 (control) & & & $71.53 \pm 2.02 \mathrm{a}$ & \\
\hline
\end{tabular}

Note: Data are presented as mean \pm SE. Different lowercase letters indicate significant differences at the 0.05 level by Tukey's test. Control means P. incisi pupae developed at $25^{\circ} \mathrm{C} .{ }^{\mathrm{E}}$ means that part of $P$. incisi have emerged during the cold storage protocol. "-" means that the emergence rate was less than $5 \%$ after pupal cold storage, and therefore excluded from the analysis.

\subsection{Effects of Pupal Cold Storage on the Quality of P. incisi Adults}

\subsubsection{Dry Weight}

Pupal cold storage lead to significant impacts on the dry weight of both sexes of post-storage $P$. incisi adults according to one-way ANOVA (female: $F_{4,40}=36.795, p<0.001$; male: $\left.F_{4,40}=22.323, p<0.001\right)$. Furthermore, based on the result of Tukey's HSD test, except for the cold storage 4 (CS4) protocol (female: $p<0.05$; male: $p<0.05$ ), all other pupal cold storage treatments did not differ from the control for the dry weight of both sex adults (Table 3).

\subsubsection{Flight Capacity}

The flight capacity of post-storage $P$. incisi adults was significantly affected by the cold storage protocol (female: $F_{4,40}=3.520, p<0.05$; male: $F_{4,40}=2.926, p<0.05$ ). CS4 lead to the lowest flight capacity of both sex adults and was significantly inferior to the control (female: $p<0.05$; male: $p<0.05$ ) (Table 3 ). 
Table 3. The dry weight of G1 P. incisi post-storage females (a) and males (b) that had been subjected to different pupal cold storage treatments $(n=9)$.

\begin{tabular}{ccccc}
\hline \multirow{2}{*}{ Treatment } & \multicolumn{2}{c}{ Dry Weight (mg) } & \multicolumn{2}{c}{ Flight Ability (\%) } \\
\cline { 2 - 5 } & Female & Male & Female & Male \\
\hline Control $\left(25^{\circ} \mathrm{C}\right)$ & $59.67 \pm 0.76 \mathrm{a}$ & $40.30 \pm 0.59 \mathrm{a}$ & $69.33 \pm 3.65 \mathrm{a}$ & $62.67 \pm 2.75 \mathrm{a}$ \\
CS1 & $59.05 \pm 0.88 \mathrm{ab}$ & $40.55 \pm 0.38 \mathrm{a}$ & $67.56 \pm 4.15 \mathrm{ab}$ & $60.22 \pm 2.99 \mathrm{ab}$ \\
CS2 & $59.15 \pm 0.59 \mathrm{ab}$ & $40.10 \pm 0.50 \mathrm{ab}$ & $60.22 \pm 1.61 \mathrm{ab}$ & $54.44 \pm 2.97 \mathrm{ab}$ \\
CS3 & $57.72 \pm 0.60 \mathrm{ab}$ & $39.24 \pm 0.34 \mathrm{ab}$ & $61.33 \pm 1.91 \mathrm{ab}$ & $55.11 \pm 2.21 \mathrm{ab}$ \\
CS4 & $56.46 \pm 0.97 \mathrm{~b}$ & $38.19 \pm 0.64 \mathrm{~b}$ & $56.67 \pm 1.86 \mathrm{~b}$ & $52.00 \pm 1.70 \mathrm{~b}$ \\
\hline
\end{tabular}

Note: CS1: Cold storage 1, late-age pupae stored at $13{ }^{\circ} \mathrm{C}$ for $10 \mathrm{~d}$; CS2: cold storage 2, middle-age pupae stored at $13{ }^{\circ} \mathrm{C}$ for $10 \mathrm{~d}$; CS3: cold storage 3, late-age late pupae stored at $13{ }^{\circ} \mathrm{C}$ for $15 \mathrm{~d}$; CS4: cold storage 4, middle-age pupae stored at $13{ }^{\circ} \mathrm{C}$ for $15 \mathrm{~d}$. Control means $P$. incisi pupae developed at $25^{\circ} \mathrm{C}$. Bars topped by the same letter do not differ significantly $(p>0.05)$ according to Tukey's HSD test (one-way ANOVA).

\subsubsection{Longevity}

For female parasitoids, pupal cold storage had significant effects on longevity (female: $\left.F_{4,70}=3.795, p<0.01\right)$, and a remarkable reduction in female longevity was observed for CS4 $(p<0.05)$. However, the longevity of males was not significantly influenced by different treatments $\left(F_{4,70}=1.669, p=0.167\right)$ (Figures 1 and 2 ).

\subsubsection{G1 Reproductive Performance and G2 Emergence Parameters}

Pre-oviposition period $\left(F_{4,70}=0.353, p=0.841\right)$, post-oviposition period $\left(F_{4,70}=2.128\right.$, $p=0.086), \mathrm{G} 2$ emergence rate $\left(F_{4,70}=0.412, p=0.799\right)$, and $\mathrm{G} 2$ female proportion $\left(F_{4,70}=\right.$ $1.864, p=0.127)$ were not significantly affected by pupal cold storage. However, significant effects were observed for total offspring per female $\left(F_{4,70}=15.245, p<0.001\right)$, daily offspring $\left(F_{4,70}=3.625, p<0.05\right)$, and oviposition period $\left(F_{4,70}=3.893, p<0.001\right)$. The highest total offspring produced by a female was in the control group, and there was a significant difference between the control in comparison to females subjected to CS2 $(p<0.05)$ and CS4 $(p<0.01)$. Furthermore, CS4 resulted in significantly lower daily offspring $(p<0.05)$ and a shorter oviposition period $(p<0.05)$ than the control (Tables 4 and 5 ).

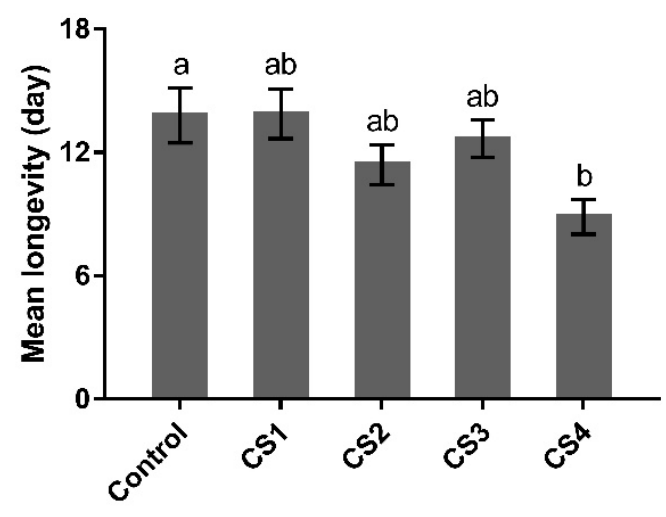

Treatment

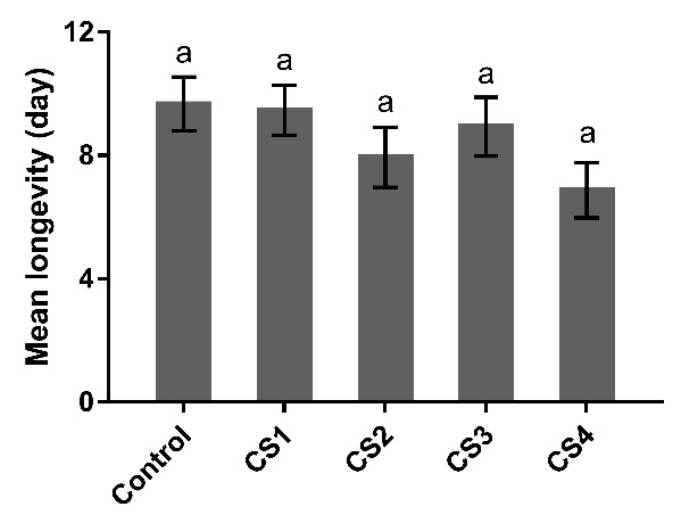

Treatment

(a)

(b)

Figure 1. Longevity of G1 P. incisi post-storage females (a) and males (b) that had been subjected to different pupal cold storage treatments. CS1: cold storage 1, late-age pupae stored at $13^{\circ} \mathrm{C}$ for $10 \mathrm{~d}$; CS2: cold storage 2, middle-age pupae stored at $13^{\circ} \mathrm{C}$ for $10 \mathrm{~d}$; CS3: cold storage 3, late-age late pupae stored at $13^{\circ} \mathrm{C}$ for $15 \mathrm{~d}$; CS4: cold storage 4, middle-age pupae stored at $13{ }^{\circ} \mathrm{C}$ for $15 \mathrm{~d}$. Control means $P$. incisi pupae developed at $25^{\circ} \mathrm{C}$. Bars topped with the same letter do not differ significantly $(p>0.05)$ according to Tukey's HSD test (one-way ANOVA) $(n=15)$. 


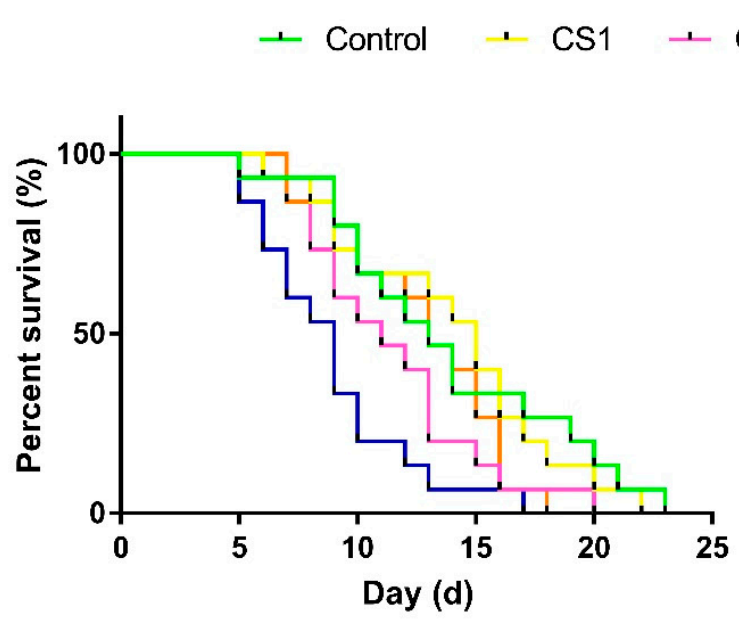

(a)

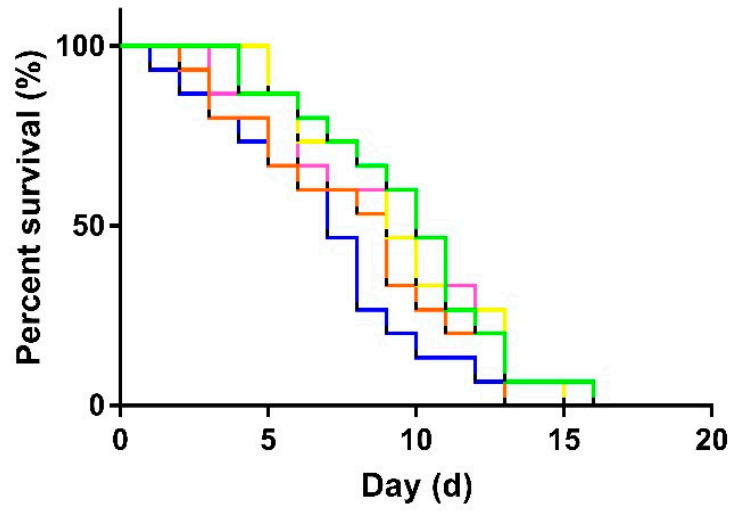

(b)

Figure 2. Survival curves of $P$. incisi post-storage female (a) and male (b) that had been subjected to different pupal cold storage treatments. CS1: cold storage 1, late-age pupae stored at $13{ }^{\circ} \mathrm{C}$ for $10 \mathrm{~d}$; CS2: cold storage 2, middle-age pupae stored at $13{ }^{\circ} \mathrm{C}$ for $10 \mathrm{~d}$; CS3: cold storage 3, late-age late pupae stored at $13^{\circ} \mathrm{C}$ for $15 \mathrm{~d}$; CS4: cold storage 4, middle-age pupae stored at $13{ }^{\circ} \mathrm{C}$ for $15 \mathrm{~d}$. Control means $P$. incisi pupae developed at $25^{\circ} \mathrm{C}(n=15)$.

Table 4. Reproductive parameters of G1 P. incisi post-storage adults $(n=15)$.

\begin{tabular}{cccccc}
\hline Treatment & $\begin{array}{c}\text { Pre-Oviposition } \\
\text { Period (d) }\end{array}$ & $\begin{array}{c}\text { Oviposition } \\
\text { Period (d) }\end{array}$ & $\begin{array}{c}\text { Post-Oviposition } \\
\text { Period (d) }\end{array}$ & $\begin{array}{c}\text { Total No. of } \\
\text { Offspring }\end{array}$ & $\begin{array}{c}\text { No. of Daily } \\
\text { Offspring }\end{array}$ \\
\hline $25{ }^{\circ}$ C (control) & $0.33 \pm 0.13 \mathrm{a}$ & $10.73 \pm 0.73 \mathrm{a}$ & $2.73 \pm 0.85 \mathrm{a}$ & $69.13 \pm 4.44 \mathrm{a}$ & $6.72 \pm 0.41 \mathrm{a}$ \\
CS1 & $0.27 \pm 0.15 \mathrm{a}$ & $11.07 \pm 0.72 \mathrm{a}$ & $2.53 \pm 0.56 \mathrm{a}$ & $68.27 \pm 3.75 \mathrm{ab}$ & $6.28 \pm 0.45 \mathrm{ab}$ \\
CS2 & $0.20 \pm 0.11 \mathrm{a}$ & $9.60 \pm 0.66 \mathrm{ab}$ & $1.60 \pm 0.42 \mathrm{a}$ & $54.80 \pm 5.51 \mathrm{~b}$ & $5.53 \pm 0.37 \mathrm{ab}$ \\
CS3 & $0.27 \pm 0.12 \mathrm{a}$ & $10.40 \pm 0.58 \mathrm{ab}$ & $2.00 \pm 0.48 \mathrm{a}$ & $65.60 \pm 3.84 \mathrm{ab}$ & $6.46 \pm 0.31 \mathrm{a}$ \\
CS4 & $0.40 \pm 0.13 \mathrm{a}$ & $7.73 \pm 0.67 \mathrm{~b}$ & $0.73 \pm 0.25 \mathrm{a}$ & $37.07 \pm 4.59 \mathrm{c}$ & $4.92 \pm 0.40 \mathrm{~b}$ \\
\hline
\end{tabular}

Note: Data are presented as mean \pm SE. Different lowercase letters indicate significant differences at the 0.05 level by Tukey's test. CS1: cold storage 1, late-age pupae stored at $13^{\circ} \mathrm{C}$ for $10 \mathrm{~d}$; CS2: cold storage 2, middle-age pupae stored at $13{ }^{\circ} \mathrm{C}$ for $10 \mathrm{~d}$; CS3: cold storage 3, late-age late pupae stored at $13{ }^{\circ} \mathrm{C}$ for $15 \mathrm{~d}$; CS4: cold storage 4 , middle-age pupae stored at $13^{\circ} \mathrm{C}$ for $15 \mathrm{~d}$. Control means P. incisi pupae developed at $25^{\circ} \mathrm{C}$.

Table 5. Emergence rate and female proportion of progeny $(\mathrm{G} 2)(n=15)$.

\begin{tabular}{ccc}
\hline Treatment & G2 Emergence Rate (\%) & G2 Female Proportion (\%) \\
\hline Control $\left(25^{\circ} \mathrm{C}\right)$ & $85.51 \pm 1.31 \mathrm{a}$ & $71.36 \pm 1.44 \mathrm{a}$ \\
CS1 & $83.75 \pm 1.20 \mathrm{a}$ & $69.43 \pm 1.13 \mathrm{a}$ \\
CS2 & $83.45 \pm 1.52 \mathrm{a}$ & $70.73 \pm 0.95 \mathrm{a}$ \\
CS3 & $83.96 \pm 1.11 \mathrm{a}$ & $71.02 \pm 0.73 \mathrm{a}$ \\
CS4 & $84.23 \pm 1.21 \mathrm{a}$ & $67.26 \pm 1.58 \mathrm{a}$ \\
\hline
\end{tabular}

Note: Data are presented as mean \pm SE. Different lowercase letters indicate significant differences at the 0.05 level by Tukey's test. CS1: cold storage 1, late-age pupae stored at $13^{\circ} \mathrm{C}$ for $10 \mathrm{~d}$; CS2: cold storage 2, middle-age pupae stored at $13^{\circ} \mathrm{C}$ for $10 \mathrm{~d}$; CS3: cold storage 3, late-age late pupae stored at $13^{\circ} \mathrm{C}$ for $15 \mathrm{~d}$; CS4: cold storage 4 , middle-age pupae stored at $13^{\circ} \mathrm{C}$ for $15 \mathrm{~d}$. Control means P. incisi pupae developed at $25^{\circ} \mathrm{C}$.

\section{Discussion}

The utilization of opiine parasitoids, especially F. arisanu, has successfully alleviated the serious damage of $B$. dorsalis to fruit products in Hawaii, which inspired other regions to adopt a biological control program for managing this pest [21]. However, today, F. arisanu has only been recorded in Zhanjiang City, Guangdong Province in China [22], which means that $F$. arisanu may not be able to be the dominant bioagent against $B$. dorsalis in some regions of China. Furthermore, considering the various ecological conditions in different regions of mainland China, it is indispensable to dig local parasitoid resources to develop the most suitable local biological control programs against $B$. dorsalis. Previous research in Zhangzhou City, Fujian Province, China, indicated that there were four parasitic wasp 
species against $B$. dorsalis, including P. incisi, Pachycrepoideus vindemmiae (Rondani), Pachycrepoideus vindemmiae (Rondani), and Spalangia endius (Walker) (Hymenoptera: Pteromalidae), of which P. incisi occupied a dominant proportion (77.6\%) of this parasitic wasp population [9]. Therefore, P. incisi is a highly suitable bioagent for biological control programs against $B$. dorsalis in that region of China.

The present study is the first, to our knowledge, that has aimed to optimize the cold storage protocol of $P$. incisi to improve the efficiency and flexibility of biological control programs against $B$. dorsalis. Our results demonstrate that storage temperature, storage duration, pupal age interval, storage temperature $\times$ storage duration, storage temperature $\times$ pupal age interval, and storage duration $\times$ pupal age interval and their interactions have significant impacts on the viability of immature P. incisi. However, when late-age P. incisi pupae were subjected to CS1 and CS3, the emergence parameters of both G1 and G2 progeny, and G1 quality parameters (including flight ability, dry weight, longevity, and reproduction parameters) did not differ significantly from the control treatment.

The essence of cold storage is to utilize a sub-optimum temperature to prolong the developmental time of a bioagent whilst maintaining its quality and effectiveness against a pest [23]. Cold storage protocols are extremely valuable for inundative biological control, given that they require large-scale production and the release of huge numbers of bioagents. However, modulating the development of bioagents via cold storage can pose lethal and sub-lethal effects to their survivorship [24,25]. In the present study, a reduction in the storage temperature or an extension of the storage period resulted in a decrease in the emergence rate of $P$. incisi. This is consistent with previous research on the cold storage of two other braconid parasitoids that are used against $B$. dorsalis, namely F. arisanus and $D$. longicaudata; these studies found that the viability of parasitized pupae was gradually reduced as the temperature decreased or the storage period was extended [16,17]. In addition, we interestingly found that middle-age $P$. incisi pupae exhibited superior performance in the emergence rate in comparison to prepupae and late-age pupae subjected to the same cold storage protocols of 4, 7, or $10^{\circ} \mathrm{C}$. Similarly, a study on Encarsia formosa (Gahan) (Hymenoptera: Aphelinidae) indicated that both early- and late-stage pupae exhibited inferior tolerance to low temperatures in comparison with mid-stage pupae, with the mid-stage pupae exhibiting higher survival rates [26].

Although cold storage clearly has advantages in enhancing the efficiency and flexibility of mass-rearing and release programs, the undesirable effects on the quality of post-storage insects are of concern. A significant amount of research has emphasized that subjecting bioagents to cold conditions can result in cold stress and excessive consumption of energy reserves, thereby influencing their quality parameters and their successful application under field conditions $[11,27]$. Our results demonstrated that the cold storage of $P$. incisi pupae was deleterious to the dry weight of post-storage adults. Lins et al. reported that the body mass loss was directly proportional to the extension in the storage period when prepupae of Praon volucre (Haliday) (Hymenoptera: Braconidae) were stored at $5{ }^{\circ} \mathrm{C}$ [28]. These weight losses during cold storage may chiefly result from the immature parasitoid wasps consuming a body of energy and lipid reserves to ensure survival during the period of low temperature. Excessive lipid loss is fatal to parasitoid adults as they cannot synthesize lipids by themselves, and thereby perform a trade-off between survivorship and fecundity, in turn affecting their lifespan [29-31]. In our study, the longevity of female P. incisi that emerged from middle-age pupae stored at $13^{\circ} \mathrm{C}$ for 15 days was significantly shorter. This is in accordance with results found in D. longicaudata [17], which revealed that females that emerged from parasitized B. doralis pupae stored below $8^{\circ} \mathrm{C}$ had a shorter lifespan than the control, regardless of the storage period. Likewise, the cold storage of other braconid wasps, such as Aphidius ervi (Haliday), Aphidius picipes (Nees), and Bracon hebetor (Say) (Hymenoptera: Braconidae), during the pupal stage, indicated a similar tendency in the longevity of post-storage adults [32-34].

Dispersibility, one of the most important quality parameters for parasitoids when considering the various, complex, and harsh field conditions they need to withstand whilst 
host-seeking, hiding from predators, and searching for resting places, is particularly vulnerable to the effects of low-temperature storage. In fact, the neuro-muscular dysfunction that can be induced by cold storage directly affects the bioagent's ability to disperse, and is a major obstacle to the practical application of post-storage insects in the field [10,35]. In concordance with this, our results demonstrated that subjecting middle-age $P$. incisi pupae to 15 days of cold storage at $13{ }^{\circ} \mathrm{C}$ resulted in the emerged adults displaying inferior flight ability. A study on E. formosa and Encarsia eremicus (Rose) (Hymenoptera: Aphelinidae) indicated that increasing the cold exposure period of pupae resulted in a reduction in the flight capacity of the emerged adults [26]. Similarly, P. volucre pre-pupae developed at a sub-ambient temperature of $5{ }^{\circ} \mathrm{C}$ exhibited lower flight capacity than the control group [28].

In addition to dispersibility, the reproductive system of bioagents is extremely susceptible to sub-optimum conditions. In our study, for middle-age $P$. insici pupae subjected to cold storage at $13{ }^{\circ} \mathrm{C}$ for 10 or 15 days, the number of progeny produced by post-storage adults was remarkably decreased. This is consistent with previous research on braconid parasitoids, whereby a reduction in fecundity was strongly associated with low temperature and storage period $[28,33,36]$. Furthermore, the reproductive parameters of $P$. incis $i$ that originated from the Zhangzhou region showed a significant difference to the Hawaii $P$. incisi strain [37]. Liang et al. [38] indicated that there was a certain difference between two geographic $P$. incisi populations by using random amplified polymorphic DNA analysis, this may account for the remarkable difference in reproductive parameters between these two strains.

The viability of mass-release biocontrol programs is largely determined by the ability to generate sufficient reserves of the bioagent in a relatively short timeframe. Furthermore, flexibility is also required in both the rearing and release schedules to deal with unforeseen factors such as adverse weather and transportation delays. As such, the cold storage technique can help mitigate these problems [39] and is increasingly undertaken as a support approach in classical biological control programs [11]. Nonetheless, the adverse effects induced by sub-ambient temperature remarkably reduce the performance of post-storage bioagents. This consequently leads to challenges in balancing the logistics of the release program with field performance. In order to minimize the losses in quantity and fitness, recent studies have primarily concentrated on optimizing the cold storage protocol of the bioagent. As such, our present study aims to provide a foundation for optimizing the cold storage technique of $P$. incisi and our results demonstrate that $P$. incisi pupae subjected to CS1 and CS3 does not result in significant adverse effects on the emergence rate and quality of post-storage adults. Such information is vital for the mass production and release of $P$. incisi as a dominant biological control agent against $B$. dorsalis in that region of China. In addition, in this study, we used microscopic examination to distinguish parasitized puparia and unparasitized puparia to facilitate scientific research. However, for the mass storage of $P$. incisi pupae for release, we still propose using physical approaches, such as utilizing the suitable mesh of net that prevents flies from escaping, while without restricting the emerged $P$. incisi. Further studies will be carried out to assess the potential control efficacy of post-storage $P$. insici against the $B$. dorsalis population under field conditions.

Author Contributions: Methodology, J.L., C.L., and Q.J.; performed the experiments, J.L., D.Y., X.H., Y.G., and S.S.; writing-original draft preparation, J.L. and P.C.; writing-review and editing, J.L. and P.C., supervision, C.L. and Q.J. All authors have read and agreed to the published version of the manuscript.

Funding: This work was funded by the Industry University Research Project of Fujian Science and Technology Department (2019N5003) and the National Key R\&D Program of China (2017YFD0202000).

Institutional Review Board Statement: Not applicable.

Informed Consent Statement: Not applicable.

Data Availability Statement: The data presented in this study are available from the corresponding author on reasonable request. 
Acknowledgments: We extend our sincerest appreciation to Shumei Wang for giving us critical suggestions regarding this research.

Conflicts of Interest: The authors declare no conflict of interest. The funders had no role in the design of the study; in the collection, analyses, or interpretation of data; in the writing of the manuscript, or in the decision to publish the results.

\section{References}

1. Liu, H.; Zhang, D.J.; Xu, Y.J.; Wang, L.; Cheng, D.F.; Qi, Y.X.; Zeng, L.; Lu, Y.Y. Invasion, expansion, and control of Bactrocera dorsalis (Hendel) in China. J. Integr. Agric. 2019, 18, 771-787. [CrossRef]

2. Clarke, A.R.; Li, Z.H.; Qin, Y.J.; Zhao, Z.H.; Liu, L.J.; Schutze, M.K. Bactrocera dorsalis (Hendel) (Diptera: Tephritidae) is not invasive through Asia: It's been there all along. J. Appl. Entomol. 2019, 143, 797-801. [CrossRef]

3. Mutamiswa, R.; Nyamukonduwa, C.; Chikowore, G.; Chidawanyika, F. Overview of oriental fruit fly, Bactrocera dorsalis (Hendel) (Diptera: Tephritidae) in Africa: From invasion, bio-ecology to sustainable management. Crop. Prot. 2021, 141, 105402. [CrossRef]

4. Piñero, J.C.; Souder, S.K.; Smith, T.R.; Vargas, R.I. Attraction of Bactrocera cucurbitae and Bactrocera dorsalis (Diptera: Tephritidae) to beer waste and other protein sources laced with ammonium acetate. Fla. Entomol. 2017, 100, 70-76. [CrossRef]

5. Jin, T.; Zeng, L.; Lin, Y.Y.; Lu, Y.Y.; Liang, G.W. Insecticide resistance of the oriental fruit fly, Bactrocera dorsalis (Hendel) (Diptera: Tephritidae), in mainland China. Pest. Manag. Sci. 2011, 67, 370-376. [CrossRef]

6. Diaz-Fleischer, F.; Perez-Staples, D.; Cabrera-Mireles, H.; Montoya, P.; Liedo, P. Novel insecticides and bait stations for the control of Anastrepha fruit flies in mango orchards. J. Pestic. Sci. 2017, 90, 1-8. [CrossRef]

7. Yang, J.Q.; Cai, P.M.; Chen, J.; Zhang, H.H.; Wang, C.; Xiang, H.J.; Yang, Y.C.; Chen, J.H.; Ji, Q.E.; Song, D.B. Interspecific competition between Fopius arisanus and Psyttalia incisi (Hymenoptera: Braconidae), parasitoids of Bactrocera dorsalis (Diptera: Tephritidae). Biol. Control 2018, 40, 183-189. [CrossRef]

8. Liang, G.H.; Chen, J.H.; Huang, J.C. The functional response and disturbance response of larvae of Psyttalia incisi (Silvestri) to oriental fruit flies. Acta Agric. Univ. Jiangxiensis 2006, 28, 200-203.

9. Liang, G.H.; Wu, Y.; Chen, J.H. Seasonal incidence of Bactrocera dorsalis and its parasitoids in field. J. Southwest For. Coll. 2006, 26, 72-74.

10. Colinet, H.; Boivin, G. Insect parasitoids cold storage: A comprehensive review of factors of variability and consequences. Biol. Control 2011, 58, 83-95. [CrossRef]

11. Rathee, M.; Ram, P. Impact of cold storage on the performance of entomophagous insects: An overview. Phytoparasitica 2018, 46, 421-449. [CrossRef]

12. Rezaei, M.; Talebi, A.A.; Fathipour, Y.; Karimzadeh, J.; Mehrabadi, M.; Reddy, G.V.P. Effects of cold storage on life-history traits of Aphidius matricariae. Entomol. Exp. Appl. 2020, 168, 800-807. [CrossRef]

13. Ghazy, N.A.; Suzuki, T.; Amano, H.; Ohyama, K. Air temperature optimisation for humidity-controlled cold storage of the predatory mites Neoseiulus californicus and Phytoseiulus persimilis (Acari: Phytoseiidae). Pest. Manag. Sci. 2014, 70, $483-487$. [CrossRef] [PubMed]

14. Lü, X.; Han, S.C.; Li, J.; Liu, J.S.; Li, Z.G. Effects of cold storage on the quality of Trichogramma dendrolimi Matsumura (Hymenoptera: Trichogrammatidae) reared on artificial medium. Pest. Manag. Sci. 2019, 75, 1328-1338. [CrossRef] [PubMed]

15. Daane, K.M.; Wang, X.G.; Johnson, M.W.; Cooper, M.L. Low temperature storage effects on two olive fruit fly parasitoids. BioControl 2013, 58, 175-185. [CrossRef]

16. Long, X.Z.; Chen, K.W.; Xian, J.D.; Lu, Y.Y.; Zeng, L. Cold storage technique of Diachasmimorpha longicaudata (Ashmead). J. Environ. Entomol. 2014, 36, 115-121.

17. Wang, H.L. Effects of Spinosad and Temperature and Humidity on the Parasitoid Fopius arisanus (Sonan). Master's Thesis, Fujian Agricultural and Forestry University, Fuzhou, China, 2011.

18. Ji, Q.E.; Dong, C.Z.; Chen, J.H. A new record species-Opius incisi Silvestri (Hymenoptera: Braconidae) parasitizing on Dacus dorsalis (Hendal) in China. Entomotaxonomia 2004, 26, 144-145.

19. Chang, C.L.; Vargas, R.I.; Caceres, C.; Jang, E.; Cho, I.K. Development and assessment of a liquid larval diet for Bactrocera dorsalis (Diptera: Tephritidae). Ann. Entomol. Soc. Am. 2006, 99, 1191-1198. [CrossRef]

20. Wang, X.G.; Messing, R.H. Potential interactions between pupal and egg-or larval-pupal parasitoids of Tephritid fruit flies. Environ. Entomol. 2004, 33, 1313-1320. [CrossRef]

21. Vargas, R.I.; Leblanc, L.; Harris, E.; Manoukis, N.C. Regional suppression of Bactrocera fruit flies (Diptera: Tephritidae) in the Pacific through biological control and prospects for future introductions into other areas of the world. Insects 2012, 3, 729-742. [CrossRef] [PubMed]

22. Yao, M.J.; Xie, C.H.; He, Y.B.; Qiu, B.; Chen, H.Y.; Xu, Z.F. Investigation on hylmenopterous parasitoids of Bactrocera dorsalis (Hendel) in Guangdong. J. Environ. Entomol. 2008, 30, 350-356.

23. Benelli, M.; Ponton, F.; Lallu, U.; Mitchell, K.A.; Taylor, P.W. Cool storage of Queensland fruit fly pupae for improved management of mass production schedules. Pest. Manag. Sci. 2019, 75, 3184-3192. [CrossRef]

24. Sakaki, S.; Jalali, M.A.; Kamali, H.; Nedved, O. Effect of low-temperature storage on the life history parameters and voracity of Hippodamia variegata (Coleoptera: Coccinellidae). Eur. J. Entomol. 2019, 116, 10-15. [CrossRef] 
25. Benelli, M.; Ponton, F.; Taylor, P.W. Cool sotrage of Queensland fruit fly eggs for increased flexibility in rearing programs. Pest. Manag. Sci. 2019, 75, 1056-1064. [CrossRef]

26. Luczynski, A.; Nyrop, J.P.; Shi, A. Influence of cold storage on pupal development and mortality during storage and on poststorage performance of Encarsia formosa and Eretmocerus eremicus (Hymenoptera: Aphelinidae). Biol. Control 2006, 40, 107-117. [CrossRef]

27. Neven, L.G.; Hansen, L.D. Effects of temperature and controlled atmospheres on codling moth metabolism. Ann. Entomol. Soc. Am. 2010, 103, 418-423. [CrossRef]

28. Lins, J.C.; Bueno, V.H.P.; Sidney, L.A.; Silva, D.B.; Sampaio, M.V.; Pereira, J.M.; Nomelini, Q.S.S.; van Lenteren, J.C. Cold storage affects mortality, body mass, lifespan, reproduction and flight capacity of Praon volucre (Hymenoptera: Braconidae). Eur. J. Entomol. 2013, 110, 263-270. [CrossRef]

29. Jervis, M.A.; Ferns, P.N.; Heimpel, G.E. Body size and the timing of egg production in parasitoid wasps: A comparative analysis. Funct. Ecol. 2003, 17, 375-383. [CrossRef]

30. Colinet, H.; Boivin, G.; Hance, T. Manipulation of parasitoid size using the temperature-size rule: Fitness consequences. Oecologia 2007, 152, 425-433. [CrossRef]

31. Visser, B.; le Lann, C.; den Blanken, F.J.; Harvey, J.A.; van Alphen, J.M.; Ellers, J. Loss of lipid synthesis as an evolutionary consequence of a parasitic lifestyle. Proc. Natl. Acad. Sci. USA 2010, 107, 8677-8682. [CrossRef] [PubMed]

32. Ismail, M.; van Baaren, J.; Hance, T.; Perre, J.S.; Vernon, P. Stress intensity and fitness in the parasitoid Aphidius ervi (Hymenoptera: Braconidae): Temperature below the development threshold combined with a fluctuating thermal regime is a must. Ecol. Entomol. 2013, 38, 355-363. [CrossRef]

33. Alam, M.S.; Alam, M.Z.; Alam, S.N.; Miah, M.R.U.; Mian, M.I.H. Effect of storage duration on the stored pupae of parasitoid Bracon hebetor (Say) and its impact on parasitoid quality. Bangladesh J. Agric. Res. 2016, 41, 297-310. [CrossRef]

34. Amice, G.; Vernon, P.; Outreman, Y.; van Alphen, J.; van Baaren, J. Variability in responses to thermal stress in parasitoids. Ecol. Entomol. 2008, 33, 701-708. [CrossRef]

35. Yocum, G.D.; Zdárek, J.; Joplin, K.H.; Lee, R.E.; Smith, D.C.; Manter, K.D.; Denlinger, D.L. Alteration of the eclosion rhythm and eclosion behavior in the flesh fly, Sarcophaga crassipalpis, by low and high temperature stress. J. Insect. Physiol. 1994, 40, 13-21. [CrossRef]

36. Yan, Z.; Yue, J.J.; Bai, C.; Peng, Z.Q.; Zhang, C.H. Effects of cold storage on the biological characteristics of Microplitis prodeniae (Hymenoptera: Braconidae). Bull. Entomol. Res. 2017, 107, 506-512. [CrossRef] [PubMed]

37. Vargas, R.I.; Ramadan, M.; Hussain, T.; Mochizuki, N.; Bautista, R.C.; Stark, J.D. Comparative demography of six fruit fly (Diptera: Tephritidae) parasitoids (Hymenoptera: Braconidae). Biol. Control 2002, 25, 30-40. [CrossRef]

38. Liang, G.H.; Huang, J.C.; Chen, J.H. Comparative analysis on RAPD of two geographic populations of Psyttalia incisi. J. Fujian Coll. For. 2007, 27, 16-19.

39. Leopold, R. Colony maintenance and mass-rearing: Using cold storage technology for extending the shelf-life of insects. In Area-Wide Control of Insect Pests: From Research to Field Implementation, 2nd ed.; Vreysen, M.J.B., Robinson, A.S., Hendrichs, J., Eds.; Springer: Dordrecht, The Netherlands, 2007; pp. 149-162. 